\title{
The Economy: A Moderate Recovery
}

OTAL SPENDING on goods and services rose at a 7.3 per cent annual rate from the third quarter of 1970 to the first quarter of 1971 , compared with a 4.6 per cent increase in the preceding year. A considerable first quarter spurt in the pace of overall economic activity can be attributed largely to a reversal of those forces accompanying work stoppages in the automobile industry late last year. First quarter gains in the auto sector accounted for about two-thirds of the $\$ 30.8$ billion increase in GNP.

Monetary growth, as measured by the narrowly defined money supply, accelerated sharply in early 1971. Most interest rates are currently higher than their February or March lows, though still well below the 1969-70 peaks. Federal Govemment expenditures, which have a short-run stimulative effect on total spending, rose more rapidly in early 1971 than in the previous two quarters.

Some progress in combating inflation has become apparent this year, while unemployment has remained at about 6 per cent of the labor force. Cutbacks in

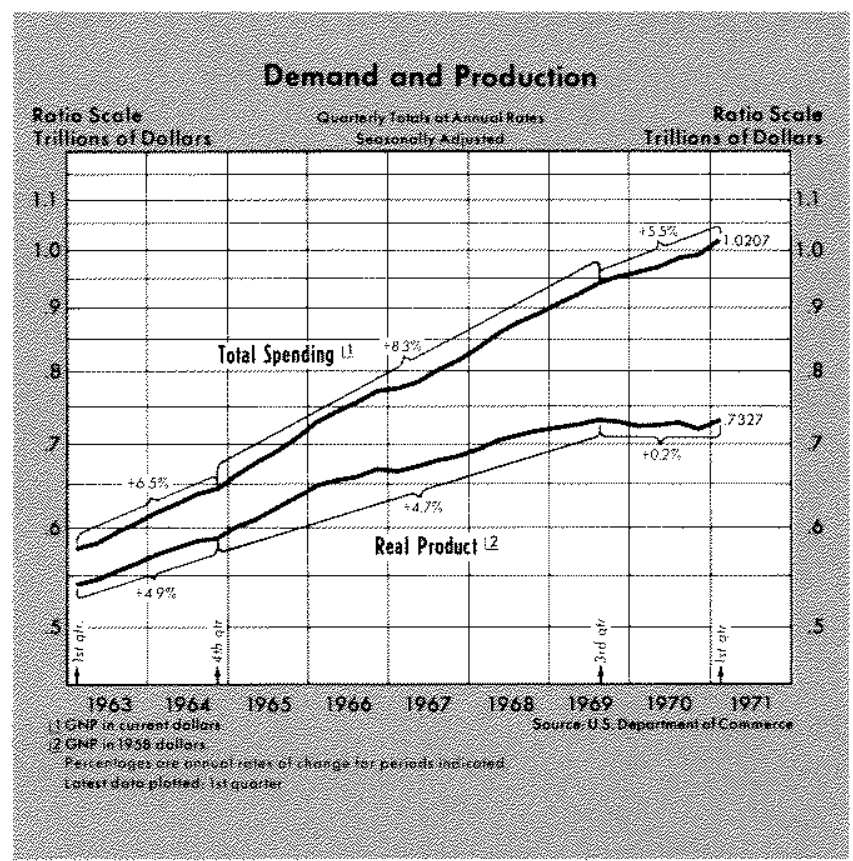

defense spending have led to significant unemploy ment in defense-related industries. Continuation of rapid monetary expansion, however, probably would be reflected in considerable gains in total spending, but would entail the risk of remforcing still formidable inflationary pressures.

\section{Stabilization Actions}

The recent monetary ease evidenced in the growth of the money stock is an extension of the expansive policies undertaken last year. The Federal budget, on a national income accounts basis, has been in sub stantial deficit since early 1970, compared with a large surplus in 1969. On a high-employment basis, which provides a better measure of fiscal stimulus, the budget has been in surplus and has changed little in recent quarters.

\section{Monetary Actions}

The monetary base, the prime determinant of growth in the money supply, increased at a 10.5 per cent rate from November to April, compared with a 6.2 per cent rate from February 1970 to November and a 2.9 per cent rate in the preceding eleven months. The growth pattern of Federal Reserve credit, the principal source component of the monetary base, has been similar to that of the base. Federal Reserve credit rose at a 13.6 per cent rate from November to April, compared with a 6.5 per cent rate from February 1970 to November and a 3 per cent rate in the preceding eleven months. Money increased at a 12.5 per cent anmual rate in the three months from January to April, after rising 4.7 per cent in the year ending in January.

The growth of the money supply over the past three months was greater than any other consecutive threemonth period since January 1950. The growth of the monetary base and Federal Reserve credit

\footnotetext{
1See "Elements of Money Stock Determination" this Review (October 1969), pp. 10-19, for an explanation of the linkages between the monetary base and the money supply.
} 


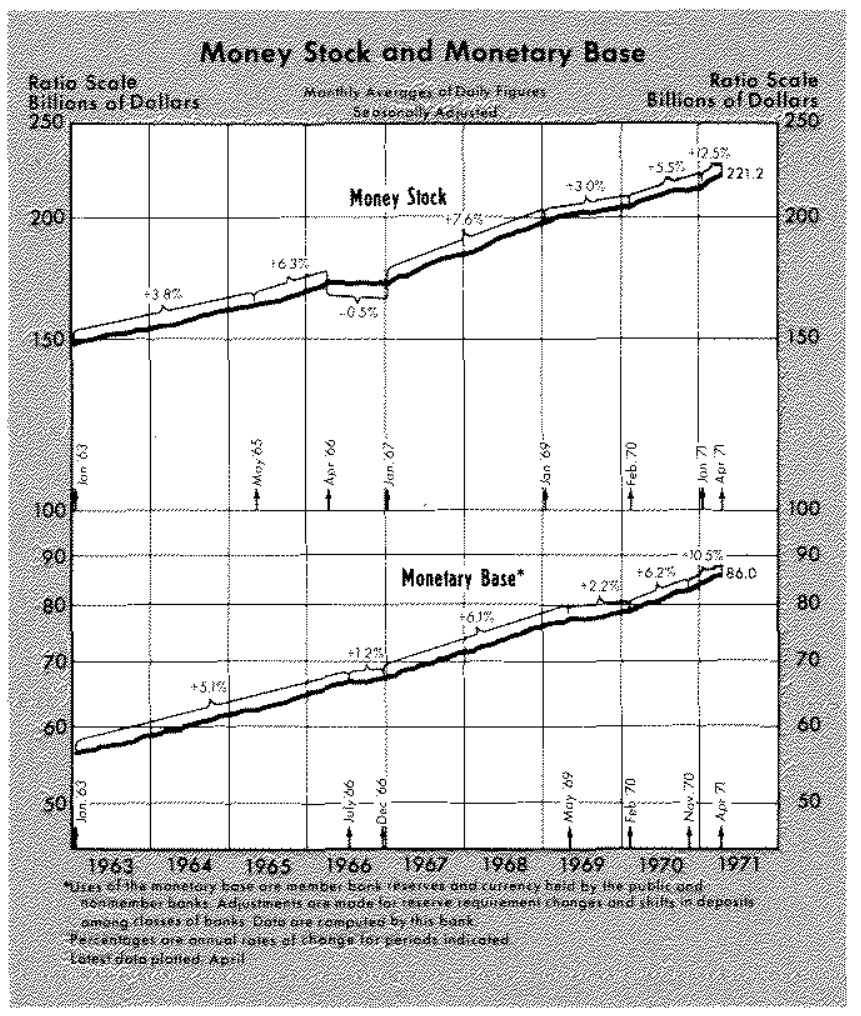

ranked in the 98th and 71st percentiles, respectively, for the same threemonth period. Such rapid growth rates of the monetary aggregates, if continued much longer, suggest future increases in total spending at rates far in excess of the growth rate of potential real output.

\section{Fiscal Actions}

Federal Government expenditures rose at an 8.4 per cent annual rate from the fourth quarter of 1970 to the first quarter of 1971 , a slightly faster rate than the 5.9 per cent annual rate of increase over the preceding two years. On a national income accounts basis, the Federal budget was in deficit at a $\$ 13.3$ billion annual rate in the first quarter of 1971., compared with an $\$ 11.5$ billion average rate of deficit in calendar year 1970. The large current deficit reflects more a shortfall in tax receipts, caused by the slowing in overall economic activity, than accelerating growth of Government expenditures. The rate of increase of Government expenditures has slowed since mid-1968. Expenditures rose at a 14.5 per cent rate from mid-1965 to mid-1968 and have risen at a 6.4 per cent rate since mid-1968.

The hypothetical high-employment budget, which reflects presumed income and expenditure patterns of the Government at at 4 per cent rate of unemployment, was in surplus at a $\$ 6.6$ billion annual rate in the first quarter, compared with an average surplus of $\$ 7$ billion in calendar year 1970 and $\$ 9.7$ billion in calendar year 1969. The high-employment budget averaged a $\$ 7.2$ billion rate of deficit from 1966 to 1968.

According to research at this Bank, fiscal actions alone, regardless of the method of measurement, have little long-run influence on total spending for goods and services, but these actions affect the transfer of goods from one sector of the economy to another. ${ }^{2}$ For example, expenditures associated with the award of a large Government defense contract require the transfer of funds from some individuals or businesses to others, when the funds are provided through taxes or bond purchases. If the Federal Reserve, rather than the public, finances the award, the end result may be an expansion of the money stock and further inflation. If the Government does not wish to enlarge its overall control of resources, the defense award could be paid for through the elimination of some other Government project.

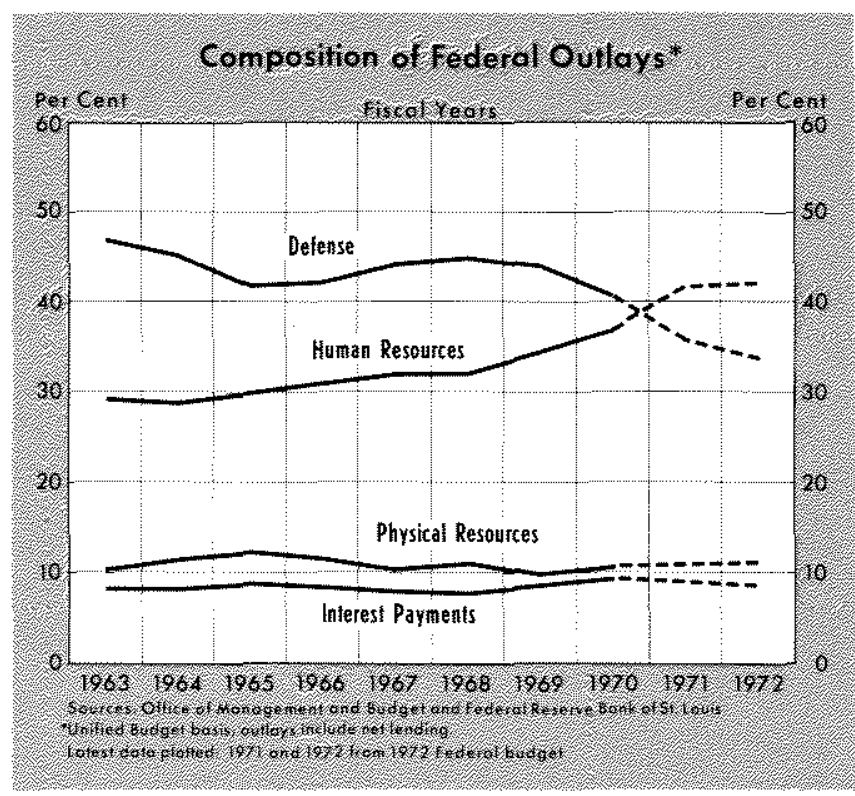

The Government allocated a greater share of its spending to human resources than to defense expenditures in the first quarter of this year. Prior to 1971 , defense spending exceeded expenditures on human resources. Both defense expenditures and total Federal outlays as a per cent of total spending peaked in mid-1968. Since then the Government has allocated a declining share of its expenditures to defense. Some effects of this shift in national priorities are evidenced by the large number of defense workers currently

-See "The 'Crowding Out' of Private Expenditures by Fiscal Policy Actions," this Review (October 1970), pp. 12-24. 


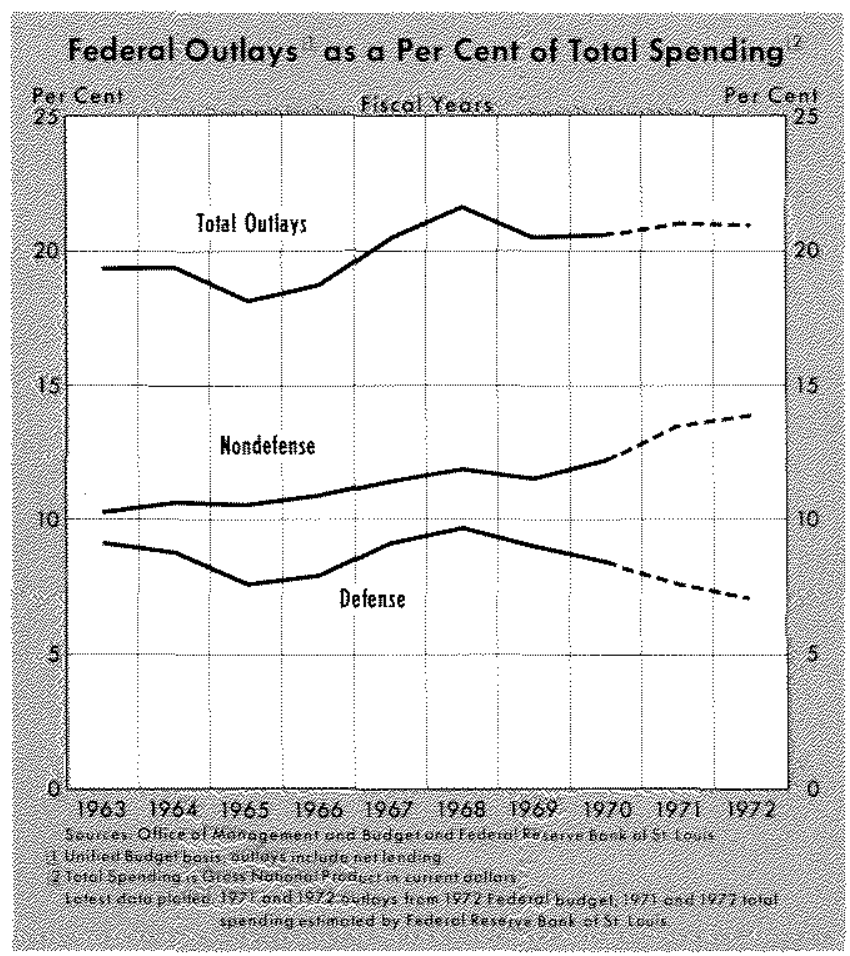

among the unemployed. Defense Department-generated employment declined at an estimated 7.9 per cent annual rate from 1968 to 1971 , after rising at a 12.2 per cent rate from 1965 to $1968 .^{3}$

\section{Output, Prices and Employment}

Recent output, employment and price trends have been obscured somewhat by the automobile work stoppages last year and preparations for a possible steel strike this summer. Allowance for these irregular fluctuations in activity, particularly the automobile strike, suggests that real output has risen slightly since the middle of last year. Rates of price increase have slowed somewhat, and the level of employment has remained about unchanged since last summer. None of these developments is necessarily inconsistent with those of the early recovery stages following other postwar recessions.

The addition (to adjust for auto strike infuences) of about $\$ 2$ billion to nominal GNP in the third quarter of last year and $\$ 14$ billion in the fourth quarter indicates that a slow recovery from a mild recession probably began in the third quarter of 1970. The accompanying chart presents an approximation of the changes in real output with and without adjustment for auto strike influences over the past year and a half. The adjusted data indicate that three quarters

3Economic Report of the President, 1971, p. 44.

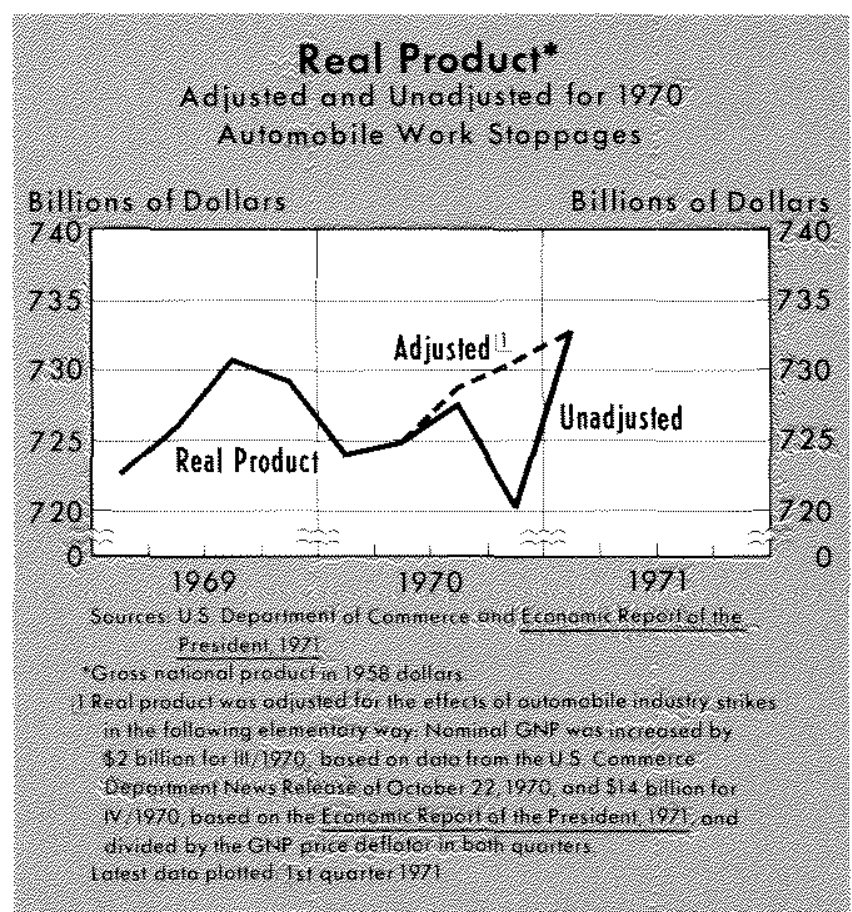

of negative or negligible growth from IV/1969 to II/1970 were followed by three quarters of moderate gains in real output from III/1970 to I/1971.

The transitory influence of the atuto strike on employment, industrial output and prices does not seriously hamper the comparison of these economic variables with past recession-recovery periods. The following chart indicates the relative mildness of the current recession-recovery in terms of payroll employment and industrial production, and the relative severity of the current inflation. Industrial production did not decline as steeply in the current recessionrecovery period as in previous comparable periods, but it also has not rebounded as sharply. In fact, industrial production in the first quarter of 1971 (six quarters after the peak) was still below the third quarter 1969 peak; industrial production on average for the three comparable earlier periods had risen above the earlier peak after six quarters. Recent data indicate that industrial production increased at a 3.7 per cent annual rate from March to April 1971, but it continued at a rate below the 1969 peak.

\section{Press}

An inspection of the consumer and wholesale price indexes suggests that some progress has been made in slowing price rises. Consumer prices rose at a 4 per cent rate from July 1970 to March 1971, compared with a 5.9 per cent increase the previous year. Wholesale prices of industrial commodities rose at a 4 per cent rate in the July-to-April period, about the same as 


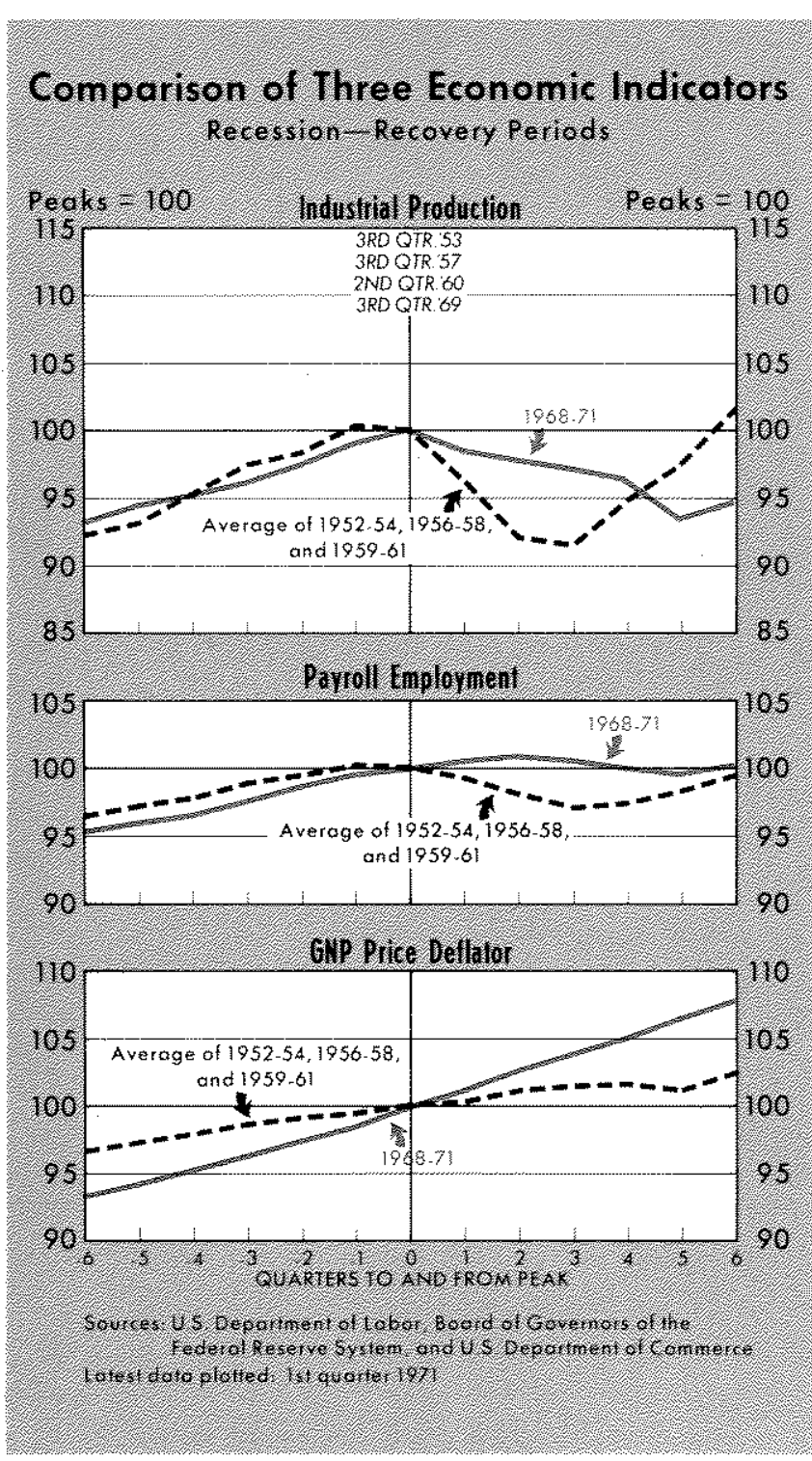

the increase in the preceding year. Wholesale prices of farm products and processed foods and feeds, a more volatile price index than most others, was about unchanged from July to April after rising 3.3 per cent the previous year.

The accompanying chart indicates that price increases began to slow a few quarters after the peak in the three comparable earlier periods, but have continued to rise rapidly since the most recent peak. The upward momentum of prices generated over the decade of the 1960's has been difficult to halt.

\section{Employment}

Both payroll and total civilian employment have been about unchanged since late last summer. Payroll employment was not cut back as much in the
1969-71 period as in the average of the three earlier periods. Six quarters after the peak, however, payroll employment was at about the level of the peaks in both the recent and the earlier periods. The fact that payroll employment did not decline or rebound as much as the average of the earlier comparable periods suggests the mildness of the latest economic slow down and recovery.

The current employment situation is similar to the 1961 recession-recovery period in terms of the gap between real and potential output, as estimated by the Council of Economic Advisers. A fairly reliable relation between real output, potential output and the unemployment rate has been established. ${ }^{*}$ The greater the gap between actual and potential output, the higher the unemployment rate. The gap between real and potential output at the end of 1961 (three quarters after the trough of the recession) was about 6.3 per cent of potential output, not substantially different from the 5.9 per cent in early 1971 . Elimination of the gap between real and potential output, which did not occur until four years after late 1961, was accompanied by a fall in unemployment to 4 per cent of the labor force or less.

The composition of the unemployed has changed since past recession-recovery periods. The trough years, 1954, 1958, and 1961, were marked by substantial unemployment among full-time, blue-collar, maxried male workers. The trough year 1970 was characterized by marked unemployment among part-time workers (all workers other than full-time workers), teenagers, and women. This changed nature of unemployment carried over into early 1971.

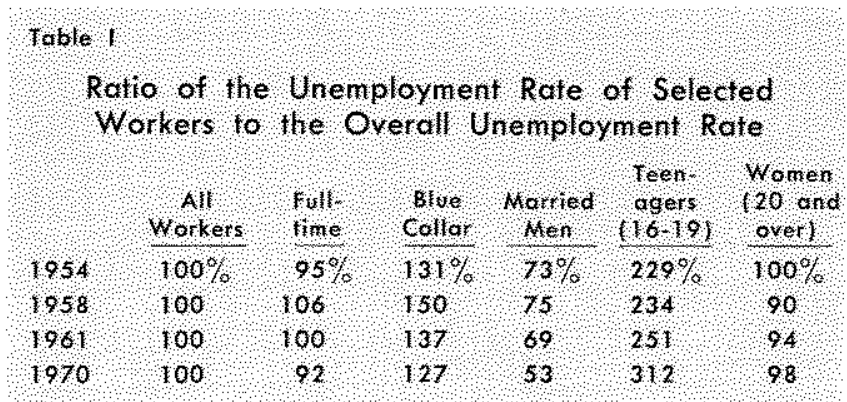

The number of employed as a proportion of the population of labor force age (16-64) was higher in 1970 than in earliex trough years, reflecting a stronger job market ant higher labor force participation rates. This ratio was 64.2 per cent in 1970 , compared with 61.8 per cent in 1961, 61.4 per cent in 1958 and 60.5 per cent in 1954.

"See "A Monetarist Model for Economic Stabilization," this Review (April 1970), pp. 7-25. 
Secular increases in the labor force participation rate of women are one probable cause for their higher unemployment, and the 1947-55 baby boom has been a strong force increasing the number of young-adult entrants into the labor force. A changing attitude toward the role of women in society, growing numbers of young workers, and an increasing supply of military veterans (whose unemployment rate is considerably higher than their civilian counterparts) will tend to assure continued rapid growth of the labor force in the near future.

\section{Spending in Major Sectors}

Among those economic sectors usually considered cyclically sensitive, residential construction activity is one of the few which has displayed strong signs of recovery in recent months. Consumer spending on durable goods has shown little strength apart from first quarter automobile sales. Spending con inventory and on plant and equipment) has also remained sluggish.

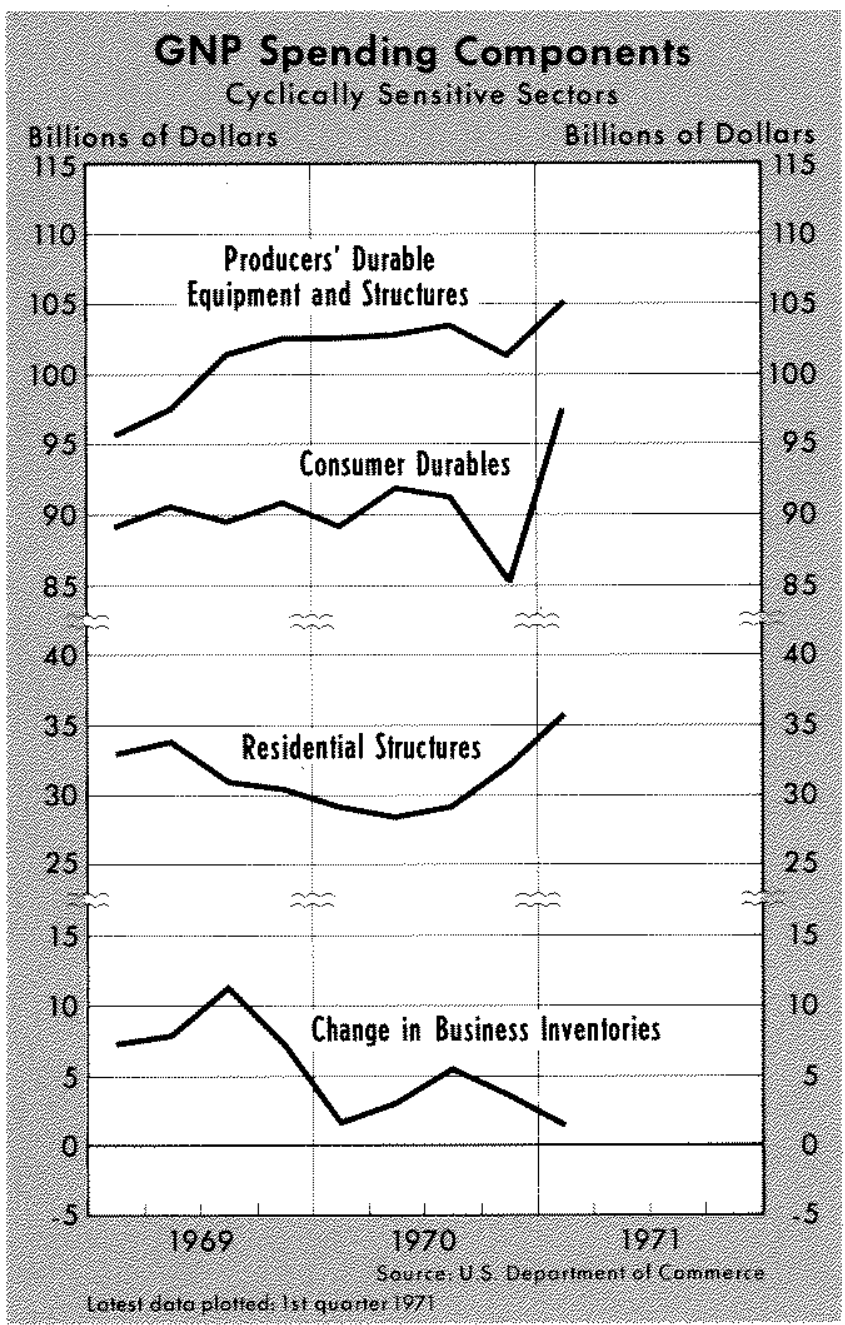

\section{Housing and Consumer Expenditures}

Residential construction continued at a brisk pace in the first quarter. From the second quarter of last year to the first quarter of 1971 , nominal spending on residential structures rose at a 36.2 per cent rate, compared with a 16.2 per cent decline in the preceding year. Falling mortgage interest rates, increased availability of funds from savings institutions, and continuing Federal housing subsidies have stimulated building activity in recent months.

New housing starts and new building permits, both of which lead actual home construction, were at a higher level in the first quarter of this year than at any quarter in more than a decade. The outlook for business structures, however, is not so favorable for the near future. Commercial and industrial construction contracts, which normally lead business construction, were at a six-year low in the first quarter.

Consumer spending, which constitutes more than 60 per cent of total spending, increased at a 7 per cent annual rate from the second quarter of last year to the first quarter of 1971 , after rising 7.2 per cent in the previous year. Consumer spending on durable goods, which is more cyclically oriented than spending on services or nondurable goods, has not rebounded strongly from a 1969-70 slump. Such spending increased at an 8.2 per cent rate from the second quarter of last year to the first quarter of 1971, compared with a 9.6 per cent annual rate of increase from 1961 to 1968.

Much of the drop in fourth quarter automobile sales was offset by first quarter post-strike purchases. A rapidly expanding money stock, a March-April surge in all retail sales (an estimated 7 per cent higher than a year earlier), improved credit conditions, and high stock market prices suggest possible future consumer spending strength. Unfavorable price and unemployment developments, however, would tend to counter a strongly optimistic consumer spending outlook.

\section{Business Spending}

Spending on producers' durable equipment and structures slowed to a 3 per cent annual rate of increase from the second quarter of 1970 to the first quarter of 1971 , down from a 5.4 per cent rise the previous year. Possibly contributing to the slowing in investment has been a fall in manufacturing capacity utilization from 79.8 per cent in the first quarter of 1970 to 73.1 per cent in the first quarter of 1971 . After-tax corporate profits, which often lead invest- 
ment activity, increased at an 11.1 per cent rate from II/1970 to $\mathrm{I} / 1971$, after falling 11.7 per cent the pre vious year. Continued profit recovery, lower interest rates, and a sustained surge in consumer spending would, if realized, spur investment spending later this year, Lengthy work stoppages and continued excess capacity would tend to restrain such spending.

Inventory spending was not strong in any quarter of 1970 nor in the first quarter of 1971. The increase of business inventories was $\$ 3.5$ billion in 1970 and $\$ 1.4$ billion (annual rate) in the first quarter of 1971 , compared with an average $\$ 9.7$ billion increase from 1965 to 1969 . The inventory-to-sales ratio did not in crease so much in early 1970 as in past recessionary periods. Consequently, inventory liquidation need not be so great as in past recovery periods. Steel inventories (as well as steel production) are expected to rise rapidly before the possible mid-summer steel strike. Steel inventories would be worked off later this year with a strike (as in 1959) or without one (as in 1968).

\section{Summary}

Total spending rose rapidly in the first quarter of this year, with much of the increase attributable to a post-strike automobile rebound. Residential construction spending has expanded rapidly in the current recovery period, but consumer, business and Federal Government spending have declined or expanded only moderately through the first quarter of this year.

Partial elimination of work stoppage influences sug. gests that a mild recovery from a mild recession has been underway since last summer. The declines in payroll employment and industrial production were not as steep as the average of three comparable earlier periods, nor has the recovery been as sharp.

Monetary actions have been very stimulative in recent months. The money supply grew at a 12.5 per cent rate from January to April, a rate greater than any other consecutive three-month period since January 1950. The monetary base and Federal Reserve credit have also risen at extremely high rates in early 1971.

Some slight signs of progress in slowing the rate of inflation emerged in the first part of 1971. Inflationary pressures, as evidenced by continuing high wage settlements, are far from being erased. Prices, preceded by monetary expansion, rose virtually unabated through the second half of the decade of the 1960's, in contrast to the 1950 's when they were slowed by policy actions on several occasions. The momentum of price increases has been much stronger recently than in the $1950^{\circ}$ s.

Policies of moderate restraint and moderate expansion were undertaken in 1969 and 1970, respectively, to slow price increases gradually. These policies of gradualism may be in jeopardy of being abandoned prematurely at the first signs of progress in arresting inflation. A repeat of the excessively stimulative policies of 1967-68 risks reversal of the modest progress achieved thus far in curbing inflation. The moderate economic slowdown of 1969.70 will have served no useful purpose if the battle against inflation is terminated short of success. In addition, the costs of slowing prices in terms of lost employment and production will be far higher in subsequent years if the current inflation and inflationary expectations are permitted to continue.

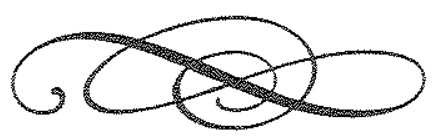

